\title{
OPTIMASI PRODUKSI ANTIBIOTIKA ISOLAT TERPILIH FUNGI ENDOFIT IKD FF-UMI 02 DARI KULIT BUAH DELIMA (Punica granatum L.) DENGAN VARIASI SUMBER KARBON
}

\author{
Rusli, Nurul Vicky Syfriani, Sumarni Hatta, Muh. Wais \\ Fakultas Farmasi Universitas Muslim Indonesia, Makassar \\ Email : rusli@umi.ac.id
}

\begin{abstract}
Research of endophytic fungi of pomegranate fruit peel (Punica granatum L.), as Anti-free radicals and antibiotic has been done with DIKTI-PKM funding at 2014. It is considered necessary to further research about optimization of antibiotic production from pomegranate fruit peel with variation of carbon source, first step is selection of isolates that have largest inhibition zone and has the most inhibit microbial test, that is endophytic fungi IKD FF-UMI 02 that has activity on Salmonella thypii, Staphylococcus epidermidis, Staphylococcus aureus and Shigella dysenteriae. Determination of growth curve from isolate by inoculating into Potato Dextrose Broth and incubated for $7 \times 24$ hours. Every 12 hours the mycelium is weighed to determine its stationary phase. Determination of optimum conditions of fermentation with carbon source such as glucose, galactose, and fructose. Endophytic fungi IKD FF-UMI 02 inoculated and fermented into production medium which is every 12 hours fermentate was taken. The activity was tested using agar diffusion method in Nutrient Agar (NA) against Salmonella thypii, Staphylococcus epidermidis, Staphylococcus aureus and Shigella dysenteriae. Resulted that growth curve of selected endophytic fungi IKD FF-UMI 02 from pomegranate fruit peel show that stationer phase starting on 192 hour and galactose carbon source is show optimum time of antibiotic production on 120 hours with inhibition zone 10,24 mm against Shigella dysenteriae.
\end{abstract}

Keywords: Optimization, antibiotic production, endophytic fungi IKD FF-UMI 02, Pomegranate fruit peel, Punica garanatum L., carbon source.

\section{PENDAHULUAN}

Fungi endofit kulit buah delima (Punica granatum L.) telah kami teliti dengan pendanaan DIKTI tahun 2014. Dari hasil penelitian kami diperoleh dari lima isolat, isolat fungi dengan kode IKD-FF-UMI 02 yang memiliki aktivitas antibiotika dan antiradikal bebas yang paling baik yang diuji dengan metode KLT-Bioautografi dan KLT-Autografi. ${ }^{1}$

Menurut Ramachandra Rao (2000), produksi metabolit sekunder yang bernilai ekonomi tinggi melalui 
Optimasi produksi antibiotika isolat terpilih fungi endofit IKD FF-UMI 02 dari kulit buah delima (Punica granatum L.) dengan variasi sumber karbon

kultur in vitro dapat diperoleh melalui beberapa metode khusus antara lain pemilihan koloni sel, pemberian prekursor, elisitasi dan manipulasi faktor lingkungan dan media. $^{2}$ Optimalisasi produksi metabolit sekunder dengan manipulasi media dapat dilakukan dengan cara manipulasi faktor fisik dan optimalisasi elemen nutrisinya. $^{5}$ Penambahan sumber karbon pada media kultur dapat meningkatkan produksi metabolit sekunder. Menurut Manuhara (1995) kandungan alkaloid vinkristin Catharanthus roseus meningkat setelah penambahan sumber karbon berupa sukrosa pada media kultur. ${ }^{3}$ Penambahan kombinasi sukrosa dan glukosa juga dapat meningkatkan kandungan saponin kultur kalus Talinum paniculatum. ${ }^{4}$

\section{Sri Aisyah (2011) dalam} penelitiannya bahwa hasil dari optimasi waktu produksi antibiotika dari isolat bakteri air laut propinsi Sulawesi Barat dengan variasi sumber karbon yang diperoleh menunjukkan aktivitas yang optimum untuk sumber karbon baik glukosa maupun fruktosa, untuk glukosa adalah jam ke-12 dan begitupun juga dengan fruktosa pada jam ke-12. Parameter waktu optimum ialah waktu dimana senyawa antibiotika diproduksi secara maksimal dan ditandai dengan terbentuknya zona hambatan yang paling besar terhadap pertumbuhan koloni bakteri. Adapun sum,ber karbon glukosa memiliki potensi lebih baik dalam menghasilkan antibiotika dibandingkan dengan fruktosa.

Hal inilah mendasari perlunya dilakukan penelitian lanjutan mengenai optimasi produksi antibiotika dari isolate terpilih IKD-FF-UMI 02 fungi endofit pada kulit buah delima dengan variasi sumber karbon.

\section{METODE PENELITIAN}

\section{Alat dan Bahan}

Alat yang dipakai Autoklaf (SMIC Model YX-280 B), cawan petri (Normax), gelas Erlenmeyer (Iwaki Pyrex), gelas kimia 250 dan $500 \mathrm{~mL}$ (Iwaki Pyrex), inkubator (Memert), Laminar Air Flow (LAF), oven (Memert), , sheaker, timbangan analitik (Chyo), dan vial. Sedangkan bahan yang digunakan yaitu air suling, etanol, Antimicrobial susceptibility test disc (oxoid), bakteri uji (Salmonella typhi dan Staphylococcus aureus), chloramphenicol, fruktosa, galaktosa, glukosa, kertas saring, medium Nutrient Agar (NA), medium Potato Dextrosa Broth (PDB). 
Optimasi produksi antibiotika isolat terpilih fungi endofit IKD FF-UMI 02 dari kulit buah delima (Punica granatum L.) dengan variasi sumber karbon

Prosedur Kerja

Pengambilan dan Penyiapan Sampel

Isolat aktif fungi endofit kulit buah delima dengan kode IKD-FF-UMI 02 dipilih dari hasil penelitian PKM (Ismail, Dian Indrawati Ulath, Muh. Khamil, Nurul Vicky Syfriani) tahun 2014 yang memiliki aktivitas paling besar (koleksi laboratorium Mikrobiologi Farmasi Universitas Muslim Indonesia) diremajakan untuk sebagai sampel pada penelitian ini.

\section{Penentuan kurva pertumbuhan}

Isolat yang terpilih

diinokulasikan ke dalam medium PDBC (PDB+Cloramphenicol) lalu diinkubasi pada suhu kamar. Pengambilan produk fermentasi dilakukan setiap interval 12 jam mulai pada jam ke-0 hingga tercapai fase stasioner. Selanjutnya sampel yang diambil setiap interval waktu tersebut ditimbang miselia yang terbentuk.

\section{Penentuan kondisi optimum fermentasi}

\section{Penentuan waktu fermentasi}

Isolat terpilih fungi endofit IKDFF-UMI 02 diinokulasikan kedalam medium produksi lalu diinkubasi pada suhu kamar selama waktu 3x24 jam (kultur starter). Sebanyak $25 \mathrm{~mL}$ kultur starter diinokulasikan ke dalam labu fermentasi yang berisi $250 \mathrm{~mL}$ medium produksi lalu diinkubasi pada suhu kamar selama 7×24 jam. Pengambilan produk fermentasi dilakukan setiap 12 jam.

\section{Penentuan komposisi medium fermentasi}

Sebanyak $25 \mathrm{~mL}$ kultur starter diinokulasikan ke dalam labu fermentasi yang berisi $250 \mathrm{~mL}$ medium produksi dengan variasi beberapa sumber karbon.

Tabel 1. Variasi komposisi medium produksi

\begin{tabular}{cccc}
\hline Komponen & \multicolumn{3}{c}{ Jumlah } \\
\cline { 2 - 4 } & M1 & M2 & M3 \\
\hline Starch & 1,5 & 1,5 & 1,5 \\
Glukosa & 1,0 & - & - \\
Fruktosa & - & 1,0 & - \\
Galaktosa & - & - & 1,0 \\
Ebios (Yeast Dried) & 0,5 & 0,5 & 0,5 \\
Pepton & 2,0 & 2,0 & 2,0 \\
NaCl & 0,25 & 0,25 & 0,25 \\
$\mathrm{CaCO}_{3}$ & 0,3 & 0,3 & 0,3 \\
\hline
\end{tabular}


Optimasi produksi antibiotika isolat terpilih fungi endofit IKD FF-UMI 02 dari kulit buah delima (Punica granatum L.) dengan variasi sumber karbon

\section{Uji Aktivitas Antibiotika}

Medium NA diambil sebanyak $10 \mathrm{~mL}$ dan ditambahkan dengan $20 \mu \mathrm{L}$ suspensi bakteri uji, kemudian dimasukkan dalam cawan petri, dibenamkan disk yang telah direndam pada hasil fermentat masing-masing isolat fungi endofit pada rentang waktu dan jenis sumber karbon selama 60 menit pada permukaan medium yang telah memadat. Kemudian diinkubasi pada suhu $37^{\circ} \mathrm{C}$ selama $1 \times 24$ jam, lalu diamati dan diukur zona hambatan yang terbentuk.

\section{HASIL PENELITIAN}

\section{Kode isolat aktif}

Isolat yang digunakan adalah IKD-FF-UMI 02 (koleksi laboratorium mikrobiologi farmasi FF-UMI) yang merupakan isolat yang memiliki zona hambatan yang paling besar dan paling banyak menghambat bakteri uji. Identifikasi isolat murni

Tabel 2. Hasil identifikasi isolat fungi endofit kode IKD-FF-UMI 02 dengan metode uji makroskopik.

\begin{tabular}{ll}
\hline Warna & Hijau \\
\hline Bentuk & Filiform \\
\hline Tepi & Lobate \\
\hline Elevasi & Hilly \\
\hline Struktur Dalam & Coarsley Granular \\
\hline
\end{tabular}

\section{Penentuan kurva pertumbuhan miselia}

Penentuan kurva pertumbuhan mikroba dilakukan dengan menggunakan medium Potato Dextrosa Broth (PDB) yang diinkubasi hingga diperoleh fase kematian dan dimana pengukuran dilakukan tiap 12 jam selama 264 jam

Tabel 3. Kurva pertumbuhan

\begin{tabular}{cc}
\hline Waktu (jam) & Berat miselia (g) \\
\hline 12 & 42 \\
24 & 48 \\
36 & 52 \\
48 & 74 \\
60 & 78 \\
72 & 81 \\
84 & 83 \\
96 & 84 \\
108 & 87 \\
120 & 87 \\
132 & 89 \\
144 & 90 \\
156 & 92 \\
168 & 93 \\
180 & 94 \\
192 & 96 \\
204 & 87 \\
216 & 73 \\
228 & 56 \\
240 & 40 \\
252 & 37 \\
264 & 36 \\
\hline
\end{tabular}

\section{Pengujian optimasi aktivitas antibiotika berdasarkan sumber karbon}

Hasil fermentasi yang telah diperoleh diuji aktivitasnya dengan 
Optimasi produksi antibiotika isolat terpilih fungi endofit IKD FF-UMI 02 dari kulit buah delima (Punica granatum L.) dengan variasi sumber karbon

metode difusi agar terhadap Shigella dysenteriae. Hasil fermentasi memperlihatkan zona hambatan, dapat dilihat pada tabel 4.

Tabel 4. Pengujian optimasi aktivitas antibiotika berdasarkan sumber karbon

\begin{tabular}{cccc}
\hline \multirow{2}{*}{$\begin{array}{c}\text { Waktu } \\
\text { (jam) }\end{array}$} & \multicolumn{3}{c}{ Diameter zona hambat (mm) } \\
berdasarkan sumber karbon
\end{tabular}

\section{PEMBAHASAN}

Berdasarkan penelitian sebelumnya (Ismail, 2014), maka pada penelitian ini digunakan isolat terpilih dengan kode IKD-FF-UMI 02 yang diujikan pada mikroba Shigella dysenteriae berdasarkan hasil identifikasinya dari isolat tersebut memiliki bentuk morfologi yaitu bentuk koloninya Filiform, tepinya berbentuk Lobate, elevasinya Hilly, dan struktur dalamnya berbentuk Coarsley Granular. ${ }^{1}$

Untuk menentukan waktu optimum produksi antibiotika dari isolat terpilih dengan kode IKD-FF-UMI 02 sebelumnya dilakukan penentuan kurva pertumbuhan. Kurva pertumbuhan mikroorganisme merupakan kurva yang menunjukkan fase-fase pertumbuhan dari mikroorganisme, yang diamati ialah fase stasionernya dimana mikroorganisme menghasilkan metabolit sekunder yaitu antibiotika.

Penentuan kurva pertumbuhan dilakukan dengan cara, isolat terpilih dengan kode IKD-FF-UMI 02 diinokulasikan dalam $250 \mathrm{~mL}$ medium potato dextrose broth lalu diinkubasi pada suhu $27{ }^{\circ} \mathrm{C}$ selama $1 \times 12$ jam. Pengambilan produk dilakukan setiap interval 12 jam yang selanjutnya diukur biomassa dari miselia yang telah dikeringkan hingga berat konstan. Berdasarkan kurva pertumbuhan yang diperoleh, diketahui bahwa fase stasioner dari isolat fungi terpilih dengan kode IKD-FF-UMI 02 mulai terjadi pada jam ke-192.

Sebelum melakukan penentuan waktu optimasi produksi antibiotika dengan cara fermentasi, terlebih 
Optimasi produksi antibiotika isolat terpilih fungi endofit IKD FF-UMI 02 dari kulit buah delima (Punica granatum L.) dengan variasi sumber karbon

dahulu dibuat kultur starter. jam. Selanjutnya dilakukan

Pembuatan kultur stalter dengan cara, dibuat suspensi isolat fungi endofit dengan menggunakan medium fermentasi sebanyak $25 \mathrm{ml}$ kultur starter diinokulasikan ke dalam labu fermentasi yang berisi $250 \mathrm{ml}$ medium fermentasi yang mengandung glukosa lalu dishaker dengan kecepatan 200 rpm selama waktu tertentu. Tujuan dishaker yaitu untuk membantu mempercepat mikroba untuk menghasilkan metabolit sekunder. Pengambilan produk fermentasi dilakukan setiap interval 24 jam mulai pada jam ke-24 hingga jam 432. Dilakukan hal yang sama untuk medium produksi yang mengandung fruktosa dan galaktosa.

Untuk penentuan waktu optimum produksi antibiotika dilakukan pengujian aktivitas antibiotika yang ditunjukkan dengan besarnya diameter zona hambat yang terbentuk. Pengujian ini dilakukan pada setiap interval 24 jam dengan metode difusi agar menggunakan medium nutrient agar (NA). Pengujian dilakukan dengan cara, diambil $2 \mathrm{ml}$ dari setiap produk fermentasi kemudian direndam paper disc selama 30 menit lalu diletakkan pada medium NA yang telah diinokulasikan bakteri uji kemudian diinkubasikan selama 1×24 pengukuran zona hambat untuk menentukan kurva produksi antibiotika selama proses fermentasi berlangsung.

Pengujian aktivitas antibiotika dilakukan terhadap bakteri uji Shigella dysenteriae penyebab disentri dan diare akut sehingga diharapkan isolat fungi endofit dari kulit buah delima dapat menghambat pertumbuhan mikroba patogen tersebut sebagai alternatif antibiotika baru.

Indikator waktu optimum ialah waktu dimana senyawa antibiotika diproduksi secara maksimal dan ditandai dengan terbentuknya zona hambatan yang paling besar terhadap pertumbuhan koloni bakteri. Dari hasil pengujian aktivitas antibiotika yang diperoleh menunjukkan bahwa waktu produksi antibiotika yang optimum untuk sumber karbon fruktosa berada pada jam ke-120 dengan diameter zona hambat $7,98 \mathrm{~mm}$, dan untuk sumber karbon glukosa berada pada jam ke-240 dengan diameter zona hambat $9,10 \mathrm{~mm}$, sedangkan sumber karbon galaktosa berada pada jam ke120 dengan diameter zona hambat 10,24 mm. Untuk penentuan variasi sumber karbon optimumnya dilakukan dengan membandingkan besar diameter zona hambat dari ketiga 
Optimasi produksi antibiotika isolat terpilih fungi endofit IKD FF-UMI 02 dari kulit buah delima (Punica granatum L.) dengan variasi sumber karbon

variasi tersebut. Hal ini ditunjukkan oleh sumber karbon galaktosa yang memiliki zona hambat yang jauh lebih besar dibanding zona hambat yang dihasilkan oleh sumber karbon fruktosa dan glukosa.

\section{Potensi hasil}

Manfaat artikel ilimiah ini bisa dijadikan referensi untuk penelitian lanjutan terhadap isolat fungi terpilih dengan kode IKD-FF-UMI 02 dan sebagai sumber rujukan untuk peneliti lainnya.

Untuk memperoleh paten masih memerlukan penelitian lebih lanjut. Yaitu dengan mengisolasi antibitika murni, kemudian dilakukan elusidasi struktur agar diperoleh senyawa antibiotika yang baru

\section{KESIMPULAN}

Berdasarkan penelitian yang telah dilakukan, dapat disimpulkan bahwa: Kurva pertumbuhan yang diperoleh dari isolat fungi terpilih dengan kode IKD-FF-UMI 02 kulit buah delima menunjukkan bahwa fase stasioner mulai terjadi pada jam ke192. Sumber karbon galaktosa adalah sumber karbon yang menunjukkan waktu optimum produksi antibiotika isolat fungi terpilih dengan kode IKDFF-UMI 02 kulit buah delima, paling cepat dengan diameter zona hambatan terbesar terhadap bakteri yang diujikan.

\section{DAFTAR PUSTAKA}

1. Ismail, Kamil A, Dian, Nurul V.Fungi Endofit Pada Kulit Buah Delima (Punica granatum L.) Sebagai Penghasil Antiradikal Bebas dan Antibiotika. Laporan PKM Penelitian, Fakultas Farmasi. Makassar: Universitas Muslim Indonesia, 2014.

2. Ramachandra RS. Biotechnological Production of Phytopharmaceuticals. Journal of Biochemistry Molecular Biology Biophysics 2000;4: 73-102.

3. Manuhara YSW. Pengaruh Manipulasi Media terhadap Kandungan Alkaloid Vinkristin Kalus Daun Catharanthus roseus L G. Don. Berkala Penelitian Hayati 1995;1: 1-7.

4. Suskendriyati H. Pertumbuhan dan Produksi Saponin Kultur Kalus Talinum paniculatum Gaertn dengan Variasi Pemberian Sumber Karbon (Skripsi). Surakarta: Jurusan Biologi F-MIPA UNS, 2003.

5. Mulabagal V, Tsay HS. Plant Cell Culture-an Alternative and efficient Source for the Production of Biologically Important Secondary Metabolites .Int J Appl Sci Eng 2004;2(1): 29-48. 